\title{
Dubai's Potential As An Integrated Logistics Hub
}

Cedwyn Fernandes, Middlesex University Dubai, U.A.E. Gwendolyn Rodrigues, University of Wollongong in Dubai, Dubai, U.A.E.

\begin{abstract}
The objective of this study is to examine the potential of Dubai as an integrated logistics hub, identify gaps and recommend polices accordingly. The key features of an integrated logistic hub are identified. The logistics performance of Dubai is compared to that of the top ranked logistics performing country, Singapore. Gaps that need to be looked into for Dubai to attain a similar status as Singapore are identified. The views of company managers in Dubai with regards to logistics facilities in Dubai are elicited using a survey method and analyzed. The study reveals that Dubai requires further development and investment to match Singapore's performance as a logistics hub. The survey results show that high rents and costs of operation will adversely impact on Dubai's status as a logistics hub. There also appears to be a logistics skill gap amongst the workforce in Dubai and this must be addressed and e-commerce must be encouraged. The regional competitors in Saudi Arabia, Egypt and Kuwait pose a challenge to Dubai's standing as a logistics hub for the region. The financial sector should be developed along with public institutions to facilitate a seamlessly integrated business environment. Much of the emphasis in developing Dubai as a logistics hub is on the physical infrastructure where the developments have been impressive. However, emphasis also needs to be given to containing inflation, developing professionals' skills, expanding the financial sector and ensuring that government regulation is conducive to business.
\end{abstract}

Keywords: Integrated Logistics Hub, Dubai, Middle East Logistics, Singapore Logistics, Logistics Performance Index

\section{INTRODUCTION}

trategies for economic growth adopted by countries have varied over a period of time (Rodrik, 2005). During the last few decades trade policy has focussed on outward-oriented growth policies (World Bank, 1993; Stiglitz, 1996). Importance was given to the establishment of Special Economic Zones as an instrument to boost employment, export and foreign exchange. These Special Economic Zones are to be catalyst in transforming the region into a business hub a key component of which is a logistics hub (Lee \& Hobday, 2003). Many countries in Asia (China, Hong Kong, Singapore, Malaysia) and the Middle East (UAE, Kuwait, Saudi Arabia) are positioning themselves to be logistic hubs by strengthening transport, connectivity and collaboration among players in the logistics chain. By establishing logistics hubs they hope to attract foreign investment into the country where companies would choose to locate due to highly developed logistics facilities and infrastructure.

Dubai, one of the seven Emirates in the UAE, is positioning itself as a world class integrated logistics hub. In the Dubai Strategic Plan ( 2007-2015) transportation and storage have been identified as one of the six building blocks for future growth, enabling Dubai's GDP to grow from US \$ 46.24 billion in 2006 to US \$ 107 billion in 2015 (Dubai Strategic Plan, 2007). Dubai's development as an integrated logistics hub will transform it into, a hub of business excellence by raising the productivity of economic sectors and maintain high production quality standards (Dubai Strategic Plan, 2007). This is necessary if Dubai is to integrate into the regional and global economy and achieve its targeted real GDP growth of $11 \%$ per year.

Dubai's greatest strength is its strategic location at the crossroads of major shipping routes linking the Indian Ocean to the Atlantic Ocean on one side and the Pacific Ocean on the other. Dubai's traditional links with the 
nearby Gulf States, the Red Sea, East Africa and the Indian sub-continent have enhanced the success of the first free zone in Jebel Ali established in 1985 (Tahir,1999). Dubai has excellent sea ports and airports, an efficient telecommunication network and wide ranging IT capabilities, as well as a skilled and disciplined workforce. The UAE would increase its competitive advantage by becoming a world class logistics hub which will not only serve the region, but also the Indian sub-continent and provide a halfway stage for goods bound for Europe from China and East Asia.

The Transport and communications sector contributed $13 \%$ of Dubai's GDP in 2005 (Dubai Statistics Center, 2006). Overall in the UAE, the transport and communication sector accounted for $10.4 \%$ of the GDP and employed 164,000 people in 2005 (UAE Interact, 2008). Ashai et al (2007) point out that "the transport and logistics cluster in the UAE enjoys a number of unique strengths, including its location, its world class infrastructure and a progressive non-bureaucratic government that has played a role in developing this cluster".

Dubai is home to some of the leading global companies in the field of transportation and logistics including DP World, Emirates Airlines Jebel Ali Free Zone (JAFZA), and Dubai World Central. Dubai has 27 areas designated as Free Zones. Amongst these with Dubai Logistics City which will focus on logistics activities and is a part of the Dubai World Central complex. Dubai now looks towards making the logistics leap and positioning itself as a world class integrated logistics hub. How realistic are these plans? The objective of the study is to examine the potential of Dubai as an integrated logistics hub, identify gaps and recommend policies accordingly. The study uses the survey method to understand the perceptions of managers with regards to the potential of Dubai as an integrated logistics hub.

This paper is organized as follows: Section 2 provides an explanation of the concept of an integrated logistics hub. In section 3 we compare the logistics infrastructure facilities available at Dubai with one of the world's best integrated logistics hub's - Singapore. Section 4 presents the finding of a survey of company managers in the UAE to understand their perceptions with regards to the potential of Dubai as an integrated logistics hub. Section 5 identifies the gaps that need to be addressed to cement Dubai's status as a premier logistics hub. Finally, Section 6 outlines conclusions and policy recommendations.

\section{INTEGRATED LOGISTICS HUBS - COUNTRY EXPERIENCE}

To remain competitive companies have to ensure that parts of the value chain are located in countries where they can take advantage of lower costs due to location factors and/or economies of scale. This must be balanced out by the resultant higher costs of transportation and lead times. Companies also need to ensure that their products are finalized geographically as near as possible to the final demand location. In order to optimize the trade off between cost efficiency and responsiveness of the supply chain, the need for integration between the different players in the supply chain is imperative. One such enabler for integration is a logistics hub which brings together the key players, manufacturers, shipping lines, air cargo companies, 3PLs and a host of logistics related service companies in a single location.

The need for these multi-modal hubs is driven by the need to optimize the cost efficiencies of sea freight with that of quicker but expensive air freight. Majdalani et al (2007) refer to the concept of converting sea transport to air transport mid destination as 'acceleration in motion' and identify the Middle East as a natural sea to air conversion hub. Their reasons for this include the Middle East already being a refueling stopover for the freight industry and its accessibility by sea. 'Acceleration in motion' if done in the Middle East region, achieves attractive reduction in transport time (approximately 5 to 7 days) while still conserving cost effective sea transport rates for half the distance.

To establish a successful logistics hub a three-step roadmap was suggested by Han, Chi and Cho (2004) for South Korea:

1. The first step is the expanding logistics capacity, including the cargo transit and transshipment capacity.

2. The second step is the establishment of value added logistics services such as assembly, packing, labeling and investigation. 
3. The third step is the presence of global logistics and business center like regional headquarters and regional distribution centers of multinational companies.

Contributing factors that make Hong Kong a successful entrepot and trade and logistics-hub were identified by Jianfa Shen (2004). These are, strategic location, free port status with freest economy, bridging role between mainland China and the world, the status of a quazi-state with high autonomy, low and simple tax system, nongovernment intervention, and excellent infrastructure such as seaport and airport. Tongzon (2004) in his study on Singapore also identifies some factors that are vital and necessary for a hub to be a successful logistics hub. Firstly, it should be strategically located, for example, along the main shipping and air routes. It should have an air terminal that provides extensive linkages and connectivity to the world. Its Seaport should be the focal point of shipping lines and have good linkage to other ports worldwide. It should have good capabilities in warehousing and related services. In addition to these facilities, there must be adequate and highly efficient infrastructure. The key features of an integrated logistics hub are shown in Figure 1 as outlined by the Singapore Ministry of Trade \& Industry Working Group on Logistics (2005) which was set up to recommend key strategies to enhance Singapore's competitiveness as a logistics hub.

Figure 1

\section{Leading Global Integrated Logistics Hub}

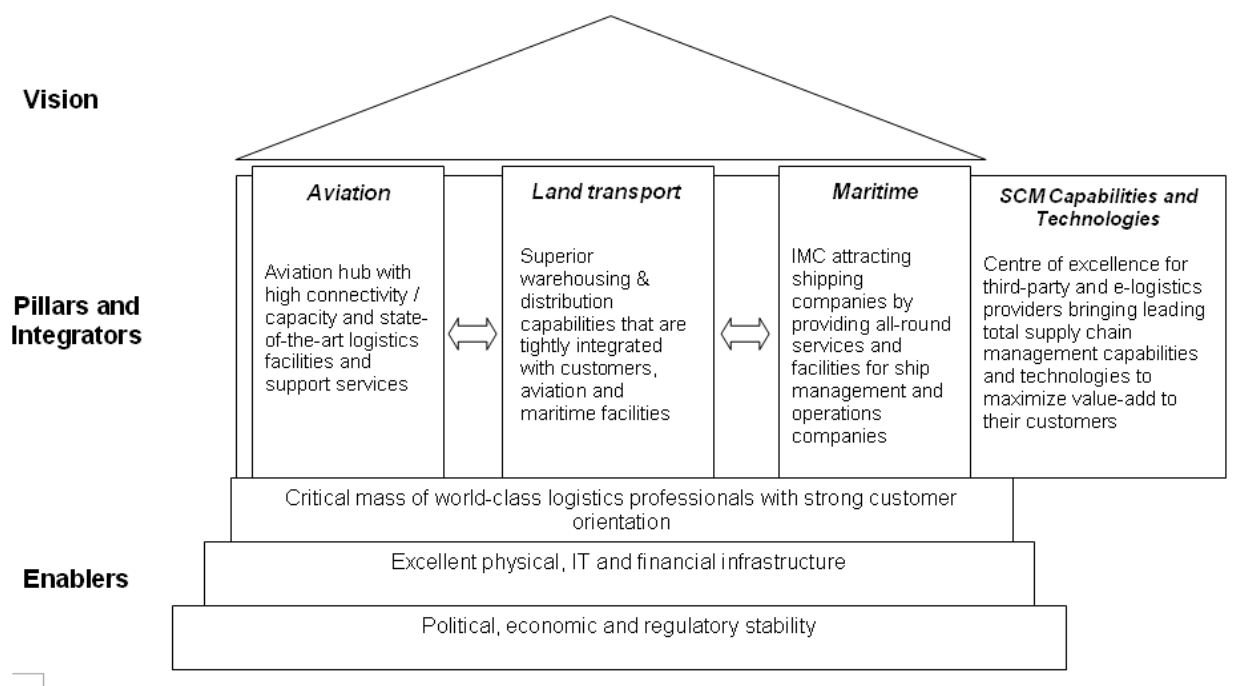

Source: Singapore Ministry of Trade \& Industry (2005)

Elements that are required for setting up of a successful regional logistics hub were identified by Al Hajiri (1999), these include:

- $\quad$ Adequate multi-modal transfer systems

- $\quad$ Good telecommunications systems

- Reasonable port charges

- $\quad$ Adequate cargo and container handling facilities

- $\quad$ Numerous berths and container terminals of various commodities, including dangerous goods

- $\quad$ Available rail and road connections to link the hub with local consumer and industrial areas.

Shippers and consignees look for the a sea-air hub where the port is approximately mid-way between the origin and destination and that the air freight cost is not more than 50 percent of the air freight cost from the origin 
to destination (Baluch, 2005) . It's not all about location and transport costs, but also about the time spent between the modes and the value added activities that can be done at the hub to realize the benefits of postponement.

Majdalani et al (2007) believe that Dubai is best positioned to become a global multi modal hub as it has some of the key features required in a integrated hub, including:

- $\quad$ An economic environment that attracts foreign firms

- $\quad$ The availability of a large free zone built around a world class port and airport

- $\quad$ Track record of port and airport operator managing complex processes

- $\quad$ Highly competitive handling charges

- $\quad$ Provision of living standards to meet the demands of a large expatriate population

Based on the above discussion the key criteria identified for the setting up an integrated logistics hub are:

- $\quad$ Strategic location - along main shipping and air routes

- World class air and sea ports

- $\quad$ Efficient and adequate logistics infrastructure

- $\quad$ Ability to provide value added services at the hub

- $\quad$ Be a part of the business hub

- $\quad$ Cost effective multi-modal transfer of cargo

- $\quad$ Reasonable port, airport and handling charges

- $\quad$ Limited government intervention and bureaucracy

The Logistics Performance Index developed by the World Bank (Arvis et al., 2007) provides a comprehensive picture of supply chain performance. Countries that are ranked high are logistics hubs and/or key players in the logistics industry. Among the 150 countries evaluated Singapore is ranked as number one in Logistics performance. In the next section we will compare Singapore and Dubai from an integrated logistics hub perspective.

\section{SECTION 3}

Logistics related facilities in Singapore and Dubai are compared with a view to identifying gaps that need to be looked at for Dubai to attain a similar status as Singapore and become a world class logistics hub. In Table 1 some key macroeconomic and demographic variables are presented. Where data for the Emirate of Dubai was not available data for $\mathrm{UAE}$ is taken to be as representative of the trend.

Singapore's GDP is 2.88 times that of Dubai, reflecting the difference in the current size of the economies of the two cities. Dubai's economy has been targeted to grow at $11 \%$ per annum and is to reach US $\$ 108$ billion by 2015 (Dubai Strategic Plan, 2007). During this period the population of Dubai is targeted to grow to 2.454 million. Dubai's land area is 6.66 times that of Singapore and will not be a constraint in its expansion plans. Singapore's status as a world class hub is reflected in the fact that Trade as a percentage of GDP is $472.3 \%$ as compared to $149.7 \%$ of Dubai.

Employment in the Transport and Communication sector in the UAE is 2.77 times that of Singapore. This is reflected in the fact that productivity of each worker for this sector in Singapore is US \$ 68,654, which is much higher than that of the UAE (US \$ 30,606). Productivity of the worker in this sector in Dubai will improve when more value added activities are implemented in Dubai. This would call for better technology and higher qualified workers

The rate of inflation in the UAE has been far greater than that of Singapore. The average rate over the period 2003-2007 was just 1.14\% in Singapore as compared to 6.72\% in the UAE. A large part of the inflation in the UAE is a result of rising rents. This has a double impact on the costs of operation for companies - higher rental costs and also a higher wage bill as companies need to compensate its workers in the form of increased accommodation 
allowances. To attract major companies to set up their operations in Dubai, inflation must be reigned in or the cost advantage of using Dubai as a hub may no longer exist.

Table 1

Macroeconomic and Demographic Variables

\begin{tabular}{|c|c|c|c|}
\hline \\
\hline+ & Singapore $^{1}$ & UAE $^{1}$ & Dubai $^{2}$ \\
\hline $\begin{array}{l}\text { Nominal GDP } \\
\text { US \$ b (2007) }\end{array}$ & 155.89 & 192.51 & 54.22 \\
\hline $\begin{array}{l}\text { Nominal GDP per Capita } \\
\text { US S (2007) }\end{array}$ & 35,142 & 43,751 & 35,437 \\
\hline $\begin{array}{l}\text { Population } \\
\text { Billion } \\
\end{array}$ & 4.44 & 4.40 & 1.53 \\
\hline $\begin{array}{l}\text { Real Growth Rate Average \% } \\
(2003-2007)\end{array}$ & 6.82 & 9.36 & 13.4 \\
\hline $\begin{array}{l}\text { Inflation } \\
\text { Average } \\
(\mathbf{2 0 0 3 - 2 0 0 7 )}\end{array}$ & 1.14 & 6.72 & 6.72 \\
\hline $\begin{array}{l}\text { Imports } \\
\text { US b (2007) }\end{array}$ & 322.65 & 103.35 & 81.57 \\
\hline $\begin{array}{l}\text { Exports } \\
\text { US b (2007) }\end{array}$ & 372.33 & 161.09 & 34.99 \\
\hline Trade as a \% of GDP & 472.3 & 131.3 & 149.7 \\
\hline $\begin{array}{l}\text { Budget Deficit/GDP } \\
\% \text { US b \$ (2007) }\end{array}$ & 6.34 & 13 & 2.46 \\
\hline $\begin{array}{l}\text { FDI } \\
\text { US b (2006) }\end{array}$ & 24.21 & 8.4 & N/A \\
\hline Transport \& Communications Sector as \% of GDP & 12 & 6.67 & $\begin{array}{c}13 \% \\
(2005)\end{array}$ \\
\hline Total Transport and Communication Sector Employment & 227,000 & 629,000 & N/A \\
\hline Land Area sq km & 622 & 83,700 & 4,144 \\
\hline
\end{tabular}

1 Business Monitor International (2008)

2 Dubai Statistics Center (2008) / IMF (2007)

Data relating to the freight and transport industry are given in Table 2.

Singapore scale of operations in sea freight is far bigger than that of Dubai and even the UAE. It highlights Singapore's status as the world's leading port in handling TEUs. Dubai's main port of Jebel Ali is currently undergoing a major expansion which will increase its capacity by 5 million TEUs in Phase 1 of the expansion which is due to be completed in 2009.

Dubai International Airport is by far the largest in the region and its capacity will increase to 75 million at the end of 2009. Dubai World Central will create the world's first truly integrated multi-modal logistics platform with all transportation modes, logistics and value-added services, such as product manufacturing and assembly in a single-bonded free zone environment made up of Dubai Logistics City, Dubai World Central International Airport and Jebel Ali Port ( DWC, 2008). The airport at Dubai World Central 'Al Maktoum International' will begin phased operations early 2009 and when fully operational by 2015 , will have a handling capacity of 120 million passengers and 12 million tones of cargo.

Dubai Logistics City (DLC) will provide facilities for companies to provide value added services, including light manufacturing and assembly, in a single customs bonded and Free Zone environment.

Dubai has an advantage over other areas as the city is in the process of being built and city planners can allocate land for activities as per the strategic vision. Dr. Hans-Peter Stabenau, Head of the German Logistics Academy of Bremen says "Dubai Logistics City is delivering a dream concept of an integrated logistics platform as it seamlessly integrates with the new international airport in Jebel Ali and the existing Jebel Ali Port and Free Zone 
for air and ocean transport infrastructure. In Europe, we missed the opportunity for such a platform and now there is no such expansive land available for integration of transport modes and logistics businesses" (DWC, 2006).

Table 2

Freight \& Transportation Variables 2007

\begin{tabular}{|c|c|c|}
\hline & Singapore & +2 \\
\hline \multicolumn{3}{|l|}{ Road } \\
\hline Tonnes $\mathrm{mn}$ & 76.51 & 161 \\
\hline$\%$ in Total & 11.9 & 8.1 \\
\hline \multicolumn{3}{|l|}{ Rail } \\
\hline Tonnes mn & 29.79 & N/A \\
\hline$\%$ in Total & 4.6 & N/A \\
\hline \multicolumn{3}{|l|}{ Water } \\
\hline Tonnes mn & 487 & 89 \\
\hline$\%$ in Total & 75.9 & 30.6 \\
\hline \multicolumn{3}{|l|}{ Air } \\
\hline Tonnes mn & 2.43 & 2.18 \\
\hline$\%$ in Total & 0.4 & 0.8 \\
\hline \multicolumn{3}{|l|}{ Pipeline } \\
\hline Tonnes mn & 43.34 & 39 \\
\hline$\%$ in Total & 7.2 & 13.4 \\
\hline \multicolumn{3}{|l|}{ Airport } \\
\hline & Changi & Dubai International \\
\hline Passengers Numbers & 36.7 million & 34.3 million \\
\hline Scheduled Airlines & 81 & 120 \\
\hline Cities Served & 185 & 205 \\
\hline Expansion Plans & & $\begin{array}{c}\text { Dubai Airport Terminal } 3 \\
\text { Capacity of airport will increase to } 75 \text { million. } \\
\text { Dubai World Central Airport } \\
\text { Capacity } 120 \text { million Passengers. }\end{array}$ \\
\hline \multicolumn{3}{|l|}{ Seaport } \\
\hline & Singapore & Dubai \\
\hline Berths & 54 & $\begin{array}{c}\text { Jebel Ali } 71 \\
\text { Port Rashid } 35\end{array}$ \\
\hline Lines Calling & 200 & 329 \\
\hline TEUs (000) & 29,577 & 10,653 \\
\hline Expansion Plans & & $\begin{array}{l}\text { Phase } 1 \text { Terminal } 1 \text { additional capacity of } 5 \mathrm{~m} \text { TEUs } \\
\text { Phase } 2 \text { Terminal } 1 \text { Additional Capacity of } 3 \mathrm{~m} \text { TEUs }\end{array}$ \\
\hline
\end{tabular}

Source: Business Monitor International - Infrastructure Report 2008

Www. caa.gov.sg www. Mpa.gov.sg

www.dubaiairport.com www.dpa.co.ae

How does Dubai compare with Singapore as per the Logistics Performance Index (LPI)? The LPI provides an index for countries and therefore we compare the LPI for UAE with that of Singapore. Dubai accounts for the major part of the logistics infrastructure in the UAE and therefore the LPI for UAE can be looked upon as representative index for Dubai. Table 3 compares the LPI and a selection of indicators for Singapore and UAE. Ranks relate to the position of Singapore or UAE amongst 150 countries that are included in the index. The score is compiled using a 5 point scale. Singapore is the number one country in the world in terms of the overall index. UAE is ranked at $20^{\text {th }}$ with an overall score of 3.73. Domestic logistics costs in both countries are high, but these are offset by lower induced costs associated with hedging for the lack of predictability and reliability of supply chains (Arvis et al 2007). The UAE and Dubai in particular has a long way to go to match up with the logistics performance of Singapore. 
Table 3

Logistics Performance Index

\begin{tabular}{|c|c|c|}
\hline & \multicolumn{2}{|l|}{ Logistics Performance Inc } \\
\hline & \begin{tabular}{|r|} 
Singapore \\
\end{tabular} & United Arab Emirates \\
\hline \multicolumn{3}{|c|}{ Logistics Performance Index } \\
\hline Rank & 1 & 20 \\
\hline Score & 4.9 & 3.73 \\
\hline \multicolumn{3}{|l|}{ Customs } \\
\hline Rank & 3 & 20 \\
\hline Score & 3.99 & 3.52 \\
\hline \multicolumn{3}{|c|}{ Infrastructure } \\
\hline Rank & 2 & 18 \\
\hline Score & 4.27 & 3.80 \\
\hline \multicolumn{3}{|c|}{ International Shipment } \\
\hline Rank & 2 & 13 \\
\hline Score & 4.04 & 3.68 \\
\hline \multicolumn{3}{|c|}{ Logistics Competence } \\
\hline Rank & 2 & 20 \\
\hline Score & 4.21 & 3.67 \\
\hline \multicolumn{3}{|c|}{ Tracking \& Tracing } \\
\hline Rank & 1 & 23 \\
\hline Score & 4.25 & 3.61 \\
\hline \multicolumn{3}{|c|}{ Domestic Logistics Cost } \\
\hline Rank & 113 & 98 \\
\hline Score & 2.78 & 2.80 \\
\hline \multicolumn{3}{|l|}{ Timelines } \\
\hline Rank & 1 & 17 \\
\hline Score & 4.53 & 4.12 \\
\hline
\end{tabular}

Source: Arvis et al., 2007

Table 4 lists data relating to logistics performance (Arvis et al., 2007) and logistics related fees in Singapore and UAE/Dubai. The UAE needs to reduce its lead times and number of border agencies involved in exports and imports. Fees at Dubai Ports and airports compare favorably with those at Singapore.

The World Bank (2008) report on Doing Business in 2008 ranks Singapore as number one country for the ease of doing business and the UAE is ranked a lowly 68. In the rankings for the ease of trading across borders Singapore ranks number one and the UAE 24. It takes 5 days for export procedures at a cost of US 416 in Singapore versus 13 days and a cost of US \$ 462 for the UAE. Import procedures take 3 days at a cost of US\$ 367 in Singapore as compared to 13 days at a cost of US\$ 462 in the UAE. The differences in costs are not as significant as compared to the time taken in import and export procedures. The emphasis should be on educing the number of procedures and the resultant time taken.

In the next section we look at what are the views of managers in Dubai as to the current logistics facilities in Dubai and what gaps exist that need to be addressed to position Dubai as a world class logistics hub. 
Table 4

Logistics Performance Data \& Charges

\begin{tabular}{|c|c|c|}
\hline & Singapore & United Arab Emirates \\
\hline Rate of Physical Inspection (percent) & 3 & 3 \\
\hline Customs Clearance (days) & 1.1 & 0.9 \\
\hline Lead time export, median case (days) & 2.4 & 3.5 \\
\hline Lead time import, median case (days) & 2.2 & 4.1 \\
\hline Number of border agencies exports & 1.5 & 3.6 \\
\hline Number of border agencies imports & 1.7 & 3.6 \\
\hline Possibility of a review procedure (percent) & 67 & 71 \\
\hline $\begin{array}{l}\text { Typical charge for a } 40 \text {-foot export container or a } \\
\text { semi-trailer (US\$) }\end{array}$ & $\$ 311$ & $\$ 291$ \\
\hline $\begin{array}{l}\text { Typical charge for a } 40 \text {-foot import container or a } \\
\text { semi-trailer (US\$) }\end{array}$ & $\$ 311$ & $\$ 298.00$ \\
\hline $\begin{array}{l}\text { Landing Fees for aircraft not exceeding } 100,000 \mathrm{kgs} \\
\text { (US \$) Changi /Dubai }\end{array}$ & $\$ 6 / 1000 \mathrm{kgs}$ & $\$ 3.18 / 1000 \mathrm{kgs}$ \\
\hline Landing Fees for aircraft exceeding $100,000 \mathrm{kgs}$ (US \$) & $\$ 7.78 / 100 \mathrm{kgs}$ & $\$ 3.48 / 1000 \mathrm{kgs}$ \\
\hline $\begin{array}{l}\text { Aircraft parking Charges } 2000 \mathrm{mts} \text { sq for } 24 \mathrm{hrs} \text { (US } \\
\text { \$) Changi /Dubai }\end{array}$ & $\$ 71.85$ & $\$ 32.44$ \\
\hline Passenger Service Chagres (US \$) Changi /Dubai & $\$ 11.11$ & Nil \\
\hline Security Charge Changi /Dubai & $\$ 4.44$ & Nil \\
\hline
\end{tabular}

Source: Arvis et al., 2007

www. Caa.gov.sg www. Mpa.gov.sg

www.dubaiairport.com www.dpa.co.ae

\section{SECTION 4}

In this section we survey company managers in Dubai to understand from their views as to what is they believe are the key elements in developing Dubai as a world class integrated logistics hub. By understanding the view from the ground, gaps will be identified and policy changes recommended. The survey questionnaire was based on the survey conducted by the Singapore Ministry of Trade \& Industry Working Group on Logistics (2005). The survey was modified to include some of the key features of an integrated logistics hub identified in Section 2.

\section{METHOD}

\section{Population, Sample, and Subjects}

The population of this study consisted of managers at all internationally owned and operated companies in Dubai across various industries and sectors. A total of 530 questionnaires were distributed by hand to the managers at their premises. Three hundred and twenty eight questionnaires were returned which is 62 percent. Out of these 305 were used and the remaining excluded for missing data or because they were filled out by other than the intended subject resulting in a 58 percent accurate reply rate.

\subsection{Company Profile}

The profile of the companies is given in Table 5. The Service industry made up $72 \%$ of the respondents. This is a reflection of the contribution of the services sector in the Dubai economy. $30 \%$ of the companies had less than 100 employees and another 30 percent over 1000 employees. The sample is representative of the companies in the UAE as defined by employee size. $29 \%$ of the companies had sales of AED 10 million or less and $31 \%$ had sales of more than AED 500 million. 
Table 5

Profile of Responding Companies

\begin{tabular}{|c|c|}
\hline & Percent \\
\hline \multicolumn{2}{|l|}{ Sector } \\
\hline Service & 71.7 \\
\hline Manufacturing & 14.2 \\
\hline Other & 14.1 \\
\hline \multicolumn{2}{|c|}{ Number of Employees } \\
\hline$<100$ & 30.6 \\
\hline $100-300$ & 17.8 \\
\hline $301-600$ & 12.8 \\
\hline $600-1000$ & 8.2 \\
\hline$>1000$ & 30.6 \\
\hline \multicolumn{2}{|c|}{ Annual sales in AED } \\
\hline$<$ AED 1million & 5.6 \\
\hline AED1 million - <AED 5 million & 12.2 \\
\hline AED 5 million - <10 million & 11.2 \\
\hline AED10m < AED 25 million & 8.2 \\
\hline AED 25 million $<$ AED50 million & 5.3 \\
\hline AED 50 million $<100$ million & 12.2 \\
\hline AED 100 million < AED 500 million & 13.8 \\
\hline$>500 \mathrm{~m}$ & 31.6 \\
\hline
\end{tabular}

\subsection{Infrastructure - Transport \& Communication}

This section deals with the strength and weaknesses of Dubai as a transport and logistics hub. Respondents were asked to mark out their response on a scale ranging from Strongly Agree to Strongly Disagree. The purpose of this section is to understand the managers' perception of current transport and communications facilities in Dubai. Results are given in Table 6.

Table 6 shows that over 90\% of the respondents Agree or Strongly Agree that the Dubai has good infrastructural facilities for it to be considered as a transport and logistics hub. Stability of the political and economic system and a strong corporate governance system has contributed substantially to the development of Dubai as an integrated logistics hub.

Over $81 \%$ of the respondents Agree or Strongly Agree with the statement that 'Relatively high rents and costs of operation including wages adversely affect Dubai's standing as a transport and logistics hub'. 58\% of the respondents Agree or Strongly Agree that there is a lack of collaboration amongst the participants in the supply chain and over 52\% of the respondents Agree or Strongly Agree that the technological advances in shipping and the airline industry may impact on liners using Dubai as a port of call. $41 \%$ of the respondents Disagree or Strongly Disagree with the statement that 'The small geographical space and low demand in the domestic market has a negative impact on UAE as a transport and logistics hub'. This implies that $59 \%$ of the respondents believe that the small size of the domestic market is a limitation of Dubai cementing its status as a regional logistics hub.

These results have some important implications for Dubai's status as a logistics hub. Technology is only going to advance and hence Dubai has to provide cost efficiencies for companies to use Dubai as their base of operations. This should be viewed in the context of the increase in rents in Dubai. Furthermore, the rising rent leading to demand for higher wages compound the problem. The small size of the domestic market makes it critical for the hub to be utilised to serve international markets and therefore all the more important for cost efficiencies to exist for companies to use Dubai as their logistics hub. 
Table 6

UAE Transport \& Communication Infrastructure

\begin{tabular}{|c|c|c|c|c|c|}
\hline $\begin{array}{l}\text { To what extent do you agree with the following } \\
\text { statements? }\end{array}$ & $\begin{array}{l}\text { Strongly } \\
\text { Agree }\end{array}$ & $\begin{array}{l}\text { Somewhat } \\
\text { Agree }\end{array}$ & $\begin{array}{l}\text { Neither } \\
\text { Agree nor } \\
\text { Disagree }\end{array}$ & $\begin{array}{l}\text { Somewhat } \\
\text { Disagree }\end{array}$ & $\begin{array}{l}\text { Strongly } \\
\text { Disagree }\end{array}$ \\
\hline & $\%$ & $\%$ & $\%$ & $\%$ & $\%$ \\
\hline $\begin{array}{l}\text { The Dubai has good infrastructural facilities for it } \\
\text { to be considered as a transport and logistics hub. }\end{array}$ & 45.4 & 42.8 & 5.3 & 4.9 & 1.6 \\
\hline $\begin{array}{l}\text { Relatively high rents and costs of operation } \\
\text { including wages adversely affect Dubai standing as } \\
\text { a transport and logistics hub. }\end{array}$ & 45.1 & 36.2 & 10.5 & 6.6 & 1.6 \\
\hline $\begin{array}{l}\text { Dubai has good connectivity with the far flung } \\
\text { manufacturing bases. }\end{array}$ & 26 & 51.3 & 15.5 & 4.9 & 2.3 \\
\hline $\begin{array}{l}\text { The small geographical space and low demand in } \\
\text { the domestic market has a negative impact on } \\
\text { Dubai as a transport and logistics hub. }\end{array}$ & 13.2 & 25.7 & 20.1 & 29.3 & 11.8 \\
\hline $\begin{array}{l}\text { Stability of the political, economic and social } \\
\text { system is necessary for development into a } \\
\text { logistics hub }\end{array}$ & 69.4 & 22.7 & 5.3 & 1.3 & 1.3 \\
\hline $\begin{array}{l}\text { There is a shortage of professional logistics skills } \\
\text { in Dubai }\end{array}$ & 22 & 39.1 & 19.1 & 12.2 & 7.6 \\
\hline $\begin{array}{l}\text { An educated workforce is an asset for the logistics } \\
\text { industry. }\end{array}$ & 57.6 & 32.9 & 8.2 & 0.7 & 0.7 \\
\hline $\begin{array}{l}\text { In Dubai there is lack of collaboration between } \\
\text { different players of the supply chain which slow } \\
\text { down the growth of the logistics hub. }\end{array}$ & 20.7 & 36.8 & 25 & 15.1 & 2.3 \\
\hline $\begin{array}{l}\text { Dubai has a sound corporate legal system that will } \\
\text { assist the development of the logistics hub. }\end{array}$ & 20.4 & 35.5 & 24 & 14.5 & 5.6 \\
\hline $\begin{array}{l}\text { Technological advances such as the increase in size } \\
\text { of ocean lines and jetliners will result in ships and } \\
\text { aircrafts preferring other trading routes rather than } \\
\text { Dubai. }\end{array}$ & 17.8 & 34.9 & 28.6 & 13.8 & 4.9 \\
\hline
\end{tabular}

Over $90 \%$ of the respondents Agree and Strongly Agree that 'An educated workforce is an asset for the logistics industry, while $61 \%$ Agree and Strongly Agree that 'In Dubai there is a shortage of professional logistics skills'. This clearly indicates a gap between the requirements for an educated workforce in the industry and what is currently available.

\subsection{Modes of Transport - Importance in an Integrated Logistics Hub}

In order to develop Dubai into an integrated logistics hub it is necessary to develop robust maritime, aviation and land transport capabilities and communication systems supporting the global economy. Respondents were asked to indicate their perception concerning the importance of each of these modes of transport on a scale ranging from Very Important to Unimportant. The results are shown in Table 7.

Over $94 \%$ of the respondents said that the development of maritime, land and air links is important or very important in an integrated logistics hub. Additionally over $75 \%$ of the respondents felt that the development of a metro rail system was important or very important in developing an integrated logistics hub. Perhaps, this is a reflection of the current road transport problems within the city of Dubai that has made movement of goods within the city, especially from the Jebel Ali Port to the Dubai International Airport a problem. The Dubai Metro Rail which is expected to begin operations in 2009 will lessen the pressure of commuter traffic on roads and free them up for transport of goods. Additionally the new Al Makhtoum International airport at Dubai World Central is expected to begin operations by 2010 will relieve the pressure on transportation of goods within the city. The new airport promises a less than 4 hour transfer time from off-loading from a ship to onboard an aircraft. 
E - Commerce is seen as key variable by $85 \%$ of the respondents. E-Commerce is still in its infancy in the UAE and a lack of e-Commerce facilities may impact on the status of Dubai as integrated regional logistics hub.

Table 7

Modes of Transport - Importance in a Logistics Hub

\begin{tabular}{|c|c|c|c|c|c|}
\hline \multirow[t]{2}{*}{$\begin{array}{l}\text { How important are the following in } \\
\text { an integrated logistics hub? }\end{array}$} & $\begin{array}{c}\text { Very } \\
\text { Important }\end{array}$ & Important & $\begin{array}{l}\text { Moderately } \\
\text { Important }\end{array}$ & $\begin{array}{c}\text { Of Little } \\
\text { Importance }\end{array}$ & Unimportant \\
\hline & $\%$ & $\%$ & $\%$ & $\%$ & $\%$ \\
\hline $\begin{array}{l}\text { An international maritime centre } \\
\text { attracting shipping companies by } \\
\text { providing all-round services and } \\
\text { facilities for ship management and } \\
\text { operation }\end{array}$ & 65.1 & 29.6 & 4.3 & 1 & 0 \\
\hline $\begin{array}{l}\text { An aviation hub with high connectivity } \\
\text { and capacity and state-of-the-art } \\
\text { logistics and support facilities }\end{array}$ & 61.8 & 33.9 & 4.3 & 0 & 0 \\
\hline $\begin{array}{l}\text { Land transport system which links to } \\
\text { warehousing facilities }\end{array}$ & 61.8 & 32.9 & 4.6 & 0.7 & 0 \\
\hline $\begin{array}{l}\text { Metro rail services with a network of } \\
\text { connections to important point } \\
\text { throughout the city. }\end{array}$ & 43.1 & 31.9 & 17.4 & 6.9 & 0.7 \\
\hline Efficiency of the postal system & 38.5 & 34.5 & 16.1 & 8.6 & 2.3 \\
\hline Telephone/Fax infrastructure & 62.2 & 28 & 6.9 & 2 & 0.7 \\
\hline $\begin{array}{l}\text { Pipelines that connect to various } \\
\text { important regional centers }\end{array}$ & 38.2 & 39.1 & 19.1 & 2 & 1.3 \\
\hline $\begin{array}{l}\text { E-commerce to facilitate trade and } \\
\text { commerce }\end{array}$ & 53.3 & 31.6 & 10.9 & 2 & 2 \\
\hline Development of an inter-modal system & 39.8 & 39.8 & 17.8 & 1.6 & 0.7 \\
\hline
\end{tabular}

Table 8

Competitors in the Region

\begin{tabular}{|l|c|c|c|c|c|}
\hline \multicolumn{1}{|c|}{$\begin{array}{c}\text { Do you agree with the following } \\
\text { statements }\end{array}$} & $\begin{array}{c}\text { Strongly } \\
\text { Agree }\end{array}$ & $\begin{array}{c}\text { Somewhat } \\
\text { Agree }\end{array}$ & $\begin{array}{c}\text { Neither } \\
\text { Agree not } \\
\text { Disagree / } \\
\text { Unsure }\end{array}$ & $\begin{array}{c}\text { Somewhat } \\
\text { Disagree }\end{array}$ & $\begin{array}{c}\text { Strongly } \\
\text { Disagree }\end{array}$ \\
\cline { 2 - 5 } & $\%$ & $\%$ & $\%$ & 18.8 & \\
\hline $\begin{array}{l}\text { Egypt: The corporate tax holiday in Egypt } \\
\text { which exempts the corporate sector from } \\
\text { taxes for 5 to 20 years will have an impact on } \\
\text { companies choosing Egypt rather than } \\
\text { JAFZA as a destination to locate their } \\
\text { operations. }\end{array}$ & 17.4 & 30.9 & 28 & 4.9 \\
\hline $\begin{array}{l}\text { Saudi Arabia: Development of free trade } \\
\text { zones and industrial cities in Saudi Arabia } \\
\text { will reduce the number of companies } \\
\text { choosing JAFZA as the free zone to locate } \\
\text { their operations. }\end{array}$ & 23.7 & 36.5 & 23.7 & 12.8 & 3.3 \\
\hline $\begin{array}{l}\text { UAE: JAFZA currently enjoys the reputation } \\
\text { of being the premier logistics hub in the } \\
\text { Middle East region. }\end{array}$ & 39.8 & 39.5 & 14.5 & 4.9 & 1.3 \\
\hline $\begin{array}{l}\text { Regional logistics hubs such as the ones in } \\
\text { Saudi Arabia and Kuwait pose a threat to } \\
\text { JAFZA as the primer logistics hub. }\end{array}$ & 23.4 & 30.3 & 19.7 & 19.4 \\
\hline
\end{tabular}

$79 \%$ of the respondents Agree or Strongly Agree that JAFZA is the premier logistics hub in the region. However, 53\% of the respondents Agree or strongly Agree that the regional hubs in Saudi Arabia and Kuwait pose a threat to JAFZA's supremacy. It is therefore imperative for JAFZA to continually upgrade its facilities and be cost efficient. 


\subsection{Competitors}

Countries in the region like Saudi Arabia and Egypt have been developing their own logistics infrastructure facilities. This section seeks the respondents view as to whether they view the development of other regional hubs as a threat to the status of Dubai as a regional logistics hub. Table 8 shows the results.

\subsection{Fees}

This section relates to fees and related charges. Respondents were asked to indicate the extent to which they believed various government regulations and fees would influence the position of Dubai as a regional logistics hub. The scale ranged from Completely Agree to Completely Disagree. Results are given in Table 9.

More than $70 \%$ of respondents Agree or Strongly Agree that seaport and airport landing fees should be reduced for Dubai to remain competitive. Land costs and costs relating to leasing in free trade zones also need to be reduced.

Table 9

Fees and Charges in Dubai

\begin{tabular}{|l|c|c|c|c|c|c|}
\hline $\begin{array}{l}\text { To what extent do you agree } \\
\text { /disagree that Dubai needs to do } \\
\text { the following to remain competitive } \\
\text { in logistics. }\end{array}$ & $\begin{array}{c}\text { Completely } \\
\text { Agree }\end{array}$ & $\begin{array}{c}\text { Mostly } \\
\text { Agree }\end{array}$ & $\begin{array}{c}\text { Slightly } \\
\text { Agree }\end{array}$ & $\begin{array}{c}\text { Slightly } \\
\text { Disagree }\end{array}$ & $\begin{array}{c}\text { Mostly } \\
\text { Disagree }\end{array}$ & $\begin{array}{c}\text { Completely } \\
\text { Disagree }\end{array}$ \\
\cline { 2 - 7 } & $\%$ & $\%$ & $\%$ & $\%$ & $\%$ & $\%$ \\
\hline $\begin{array}{l}\text { Reduction of seaport dues to remain } \\
\text { competitive }\end{array}$ & 31.6 & 41 & 21 & 3.9 & 2.6 & 0.3 \\
\hline $\begin{array}{l}\text { Reduction of airport landing/ parking } \\
\text { charges to remain competitive }\end{array}$ & 34.2 & 38 & 18 & 7.9 & 2 & 0.3 \\
\hline $\begin{array}{l}\text { Remove land premium and quit } \\
\text { rentals for companies leasing land in } \\
\text { the free trade zones in Dubai }\end{array}$ & 35.5 & 30 & 21 & 10.2 & 1 & 2.3 \\
\hline $\begin{array}{l}\text { Reduce land cost near the sea and } \\
\text { airport areas, and extend land tenure } \\
\text { without additional premiums }\end{array}$ & 39.5 & 31 & 18 & 6.6 & 2.3 & 2 \\
\hline
\end{tabular}

Table 10

Government Regulations

\begin{tabular}{|c|c|c|c|c|}
\hline \multirow{2}{*}{$\begin{array}{l}\text { To what extent do you agree with the following } \\
\text { statements that will strengthen Dubai's position as an } \\
\text { integrated logistics hub? }\end{array}$} & $\begin{array}{l}\text { To a Great } \\
\text { Extent }\end{array}$ & Somewhat & Very Little & $\begin{array}{l}\text { Not At } \\
\text { All }\end{array}$ \\
\hline & $\%$ & $\%$ & $\%$ & $\%$ \\
\hline $\begin{array}{l}\text { Special incentives which allow trusted logistics } \\
\text { companies to break-bulk (i.e., deconsolidate both local } \\
\text { and transshipment cargo) close to their own factory } \\
\text { premises outside the FTZ }\end{array}$ & 55.6 & 37.2 & 5.6 & 1.6 \\
\hline $\begin{array}{l}\text { Review bonded warehouse regulations to ensure } \\
\text { maximum utilization of warehouse space. }\end{array}$ & 52 & 35.9 & 11 & 1.6 \\
\hline $\begin{array}{l}\text { Allow pre-clearance of cargo. In some countries this } \\
\text { facility is allowed only to air express companies. This } \\
\text { facility should be extended to other logistic companies }\end{array}$ & 48 & 42.1 & 7.9 & 2 \\
\hline $\begin{array}{l}\text { The government should review the regulation of } \\
\text { dangerous goods. These should be product specific } \\
\text { rather than category -specific licenses. }\end{array}$ & 45.7 & 39.8 & 11 & 3.9 \\
\hline $\begin{array}{l}\text { The government should liberalize its policy on } \\
\text { regulation of labor to logistic companies }\end{array}$ & 55.3 & 33.6 & 9.2 & 2 \\
\hline $\begin{array}{l}\text { Streamlining checks on tankers calling at ports in the } \\
\text { Dubai and introducing a standardized vetting procedure. }\end{array}$ & 43.4 & 44.4 & 8.9 & 3.3 \\
\hline
\end{tabular}

$90 \%$ of the respondents were of the opinion that pre-clearance of cargo should be extended to logistics companies. $86 \%$ believed that review of regulations with regards to Dangerous Cargo would help to a Great Extent or somewhat in attracting new companies to Dubai. $89 \%$ of the respondents were of the opinion that liberalisation in labour laws would attract to a Great Extent or Somewhat companies to consider Dubai as a destination to move to. 


\subsection{Government Regulation}

Government regulation is mainly in the form of rules applicable to the logistics activities of companies. Respondents were asked to state the likelihood of an improvement in the inflow of industries to the logistics hub in UAE with changes in regulations. The scale ranged from 'To a Great Extent' to 'Not at All'. Results are shown in Table 10.

\subsection{Role of Public Institutions}

Change in public institutions in a number of countries has contributed to the success of the regional integrated logistic hubs. Respondents were asked to list on a scale of Almost Always True to Almost Never True which of these public institutions contributes to the establishment of an integrated logistics hub. Results are given in Table 11.

Table 11

Role of Public Institutions

\begin{tabular}{|l|c|c|c|c|c|c|c|}
\hline $\begin{array}{c}\text { The role of the following public } \\
\text { institutions is critical to } \\
\text { strengthen Dubai's position as } \\
\text { an integrated logistics hub }\end{array}$ & $\begin{array}{c}\text { Almost } \\
\text { Always } \\
\text { TRUE }\end{array}$ & $\begin{array}{c}\text { Usually } \\
\text { TRUE }\end{array}$ & $\begin{array}{c}\text { Often } \\
\text { TRUE }\end{array}$ & $\begin{array}{c}\text { Occasion- } \\
\text { ally TRUE }\end{array}$ & $\begin{array}{c}\text { Sometimes } \\
\text { But } \\
\text { Infrequent } \\
\text { ly True }\end{array}$ & $\begin{array}{c}\text { Usually } \\
\text { Not } \\
\text { True }\end{array}$ & $\begin{array}{c}\text { Almost } \\
\text { Never } \\
\text { True }\end{array}$ \\
\cline { 2 - 8 } \\
\hline Judicial Independence & 32 & 33 & 17 & 11.5 & 3 & 1.6 & 1 \\
\hline Efficiency of Legal Framework & 37 & 35 & 17 & 6.6 & 3.6 & 0.3 & 0.3 \\
\hline Property Rights & 30 & 39 & 19 & 8.6 & 1.6 & 1.3 & 0.3 \\
\hline Intellectual Property Rights & 26 & 41 & 17 & 8.9 & 3.3 & 2.6 & 1 \\
\hline Freedom of Press & 24 & 27 & 24 & 14.1 & 5.6 & 2 & 2.6 \\
\hline $\begin{array}{l}\text { Burden of Government } \\
\text { Regulation }\end{array}$ & 22 & 34 & 18 & 15.1 & 5.9 & 3 & 2.6 \\
\hline $\begin{array}{l}\text { Transparency of Government } \\
\text { Policy Making }\end{array}$ & 38 & 28 & 14 & 8.9 & 6.9 & 2.6 & 1.6 \\
\hline $\begin{array}{l}\text { Favoritism of Decision of } \\
\text { Government Officials }\end{array}$ & 20 & 30 & 19 & 14.8 & 6.6 & 5.6 & 4.3 \\
\hline $\begin{array}{l}\text { Effectiveness of Law Making } \\
\text { Bodies }\end{array}$ & 32 & 32 & 19 & 8.9 & 4.6 & 2 \\
\hline Reliability of Police Service & 35 & 32 & 14 & 10.5 & 6.3 & 1.6 & 0.7 \\
\hline Business Cost of Corruption & 25 & 33 & 19 & 13.2 & 4.9 & 3.9 & 2 \\
\hline
\end{tabular}

Judicial independence, Efficiency of Legal Framework, Property Rights and Intellectual Property Rights were ranked Almost Always True or Usually True for around $70 \%$ of the Respondents. Around 50\% of the Respondents ranked all other variables either Almost Always True or Usually True.

\subsection{Macro-economic Environment}

Development of the macroeconomic environment is crucial to the growth and stability in any country. Respondents were asked to rate the quality of a range of macro economic factors in Dubai. The scale ranged from Extremely Poor to Excellent. Table 12 tabulates the results.

Much of the weakness in the macroeconomic environment relates to the financial sector. Around $66 \%$ of the respondents are of the opinion that Financial markets sophistication is Average or Below Average. 59\% of the respondents believe that the Availability of Venture Capital is Average or Below Average.

Surprisingly above $75 \%$ of the respondents rate hidden trade barriers as Average or Below Average, indicating that in spite of the GCC Customs Union there are many hidden trade barriers especially with trade between GCC countries. 
Table 12

Macroeconomic Environment

\begin{tabular}{|l|c|c|c|c|c|}
\hline \multicolumn{1}{|c|}{$\begin{array}{c}\text { How do you rank the following in } \\
\text { Dubai? }\end{array}$} & $\begin{array}{c}\text { Extremely } \\
\text { Poor }\end{array}$ & $\begin{array}{c}\text { Below } \\
\text { Average }\end{array}$ & Average & $\begin{array}{c}\text { Above } \\
\text { Average }\end{array}$ & Excellent \\
\cline { 2 - 6 } & $\%$ & $\%$ & $\%$ & $\%$ & $\%$ \\
\hline Soundness of Banks & 4.3 & 9.5 & 31.9 & 30.3 & 24 \\
\hline Financial Market Sophistication & 3.9 & 21.1 & 41.8 & 21.4 & 11.8 \\
\hline Venture Capital Availability & 4.9 & 16.1 & 38.2 & 28.9 & 26 \\
\hline Ease of Access to Loans & 4.6 & 9.5 & 23.7 & 35.5 & 27.6 \\
\hline Regulation of Security Exchange & 3.9 & 17.4 & 42.4 & 27 & 2 \\
\hline Existence of hidden trade barriers & 5.9 & 26.3 & 43.1 & 22.7 & 21.7 \\
\hline $\begin{array}{l}\text { Ease with which Foreign equipment can } \\
\text { be Imported }\end{array}$ & 1.3 & 12.5 & 26 & 38.5 & 16.8 \\
\hline Efficiency of Customs Procedure & 3 & 9.9 & 27.6 & 42.8 & 3.5 \\
\hline Openness of Customs regime & 3.3 & 10.5 & 34.2 & 39.5 & 12.5 \\
\hline $\begin{array}{l}\text { Organized Effort to Improve } \\
\text { Competitiveness }\end{array}$ & 3.6 & 10.2 & 30.6 & 42.4 & 13.2 \\
\hline
\end{tabular}

\section{SECTION 5}

\section{Policy Recommendations and Conclusions}

Section 3 highlights the differences by comparing the logistics related facilities' and costs at Singapore and Dubai. Section 4 looks at how current logistics facilities in Dubai are perceived by managers and what needs to be addressed if Dubai is to become a world class logistics hub. In this section we look at what policy recommendations can be made in order to try and overcome these obstacles.

The physical logistics infrastructure in Dubai is excellent and on par with those of a world class integrated hub. With the Jebel Ali Port expansion and the opening of the Dubai World Central Dubai will add to its state of the art infrastructural facilities.

The biggest concern is that of Dubai retaining its cost advantages due to the high rate of inflation. This has been mainly fuelled by rising rents and subsequent increase in labour costs. In order to attract major logistics players to set up large operations in Dubai, the Free zone authorities should allot land at preferential rates to these companies and also provide accommodation for workers at cheaper than market rates. This has been done to some extent in Dubai Logistics City where a worker residential city is being built. However, the Free zone authorities should not price these facilities and services at market rates but be aware of the big picture and the overall contribution to the economy of these companies.

Companies in Dubai need to understand more fully the benefit of collaboration amongst various players in the supply chain. Dubai imports more than 90 per cent of its consumer products and the order and transport lead times are substantial. A better understanding of how collaboration can increase efficiencies and responsiveness of the supply chain is required. One way to go about it is for research to indicate benefits of collaboration and this could be done by the industry funding supply chain research centres at Universities and for the supply chain trade groups to make their members aware of collaborative opportunities and benefits and benchmark these with the best internationally.

The Gulf Cooperation Council (GCC) Union is an economic union consisting of Bahrain, Kuwait, Oman, Saudi Arabia, Qatar and UAE. The GCC union has extended the size of the market substantially for companies in the UAE as the total population of GCC countries is estimated at 35.65 million. In addition to this due to it efficient logistics facilities' and Customs inspections much of the goods are routed via Dubai. Policy makers should aggressively pursue the proposed Monetary Union so as to cement the benefits of being part of the GCC. Attention also should be paid to hidden trade barriers such as unnecessary administrative delays at GCC countries borders which are hampering the free flow of goods. 
Managers are of the opinion that there is a shortage of professional skills in the logistics industry. The recent influx of universities into Dubai has sought to redress this imbalance by offering degree and certificate programs in logistics. Professional organizations in supply chain and logistics should set up their chapters in the region and aggressively pursue training and certification opportunities in Dubai.

E-Commerce has not yet taken off in the UAE mainly due to the lack of e-payments gateways. The banking system needs to set up gateways and standards for payments between the different companies.

The Customs authorities should extend the pre-clearance of cargo facility to logistics companies thus reduce lead times. The Free Zone authorities have targeted a 4 hour time from the port in Jebel Ali onto a cargo aircraft at the Dubai World Central Al Makhtoum Airport and this will involve pre-clearance of cargo.

The government needs to ensure that its public institutions facilitate a conducive business environment. Setting up of additional judicial courts to settle business disputes quickly, protecting property rights and intellectual property rights should be high on the agenda.

In conclusion, Dubai has some way to go before it can match the performance of Singapore as a logistics hub. The good news is that massive infrastructural developments have been initiated to position Dubai as a world class logistics hub. Along with the physical infrastructural developments progress has been made in developing the financial markets, improving the corporate governance system and logistics related education and research will change the logistics landscape dramatically for the better. Dubai is on its way to becoming a world class logistics hub. The physical infrastructure is in place, attention now needs to be paid to human resources and ensuring a government regulation system conducive to business.

\section{AUTHOR INFORMATION}

Cedwyn Fernandes' is the Head of the MBA program at Middlesex University Dubai. Cedwyn's research has focused on regional economic and management issues such as building an econometric model for the United Arab Economy, Internet Banking, Leadership and management models and their applicability in a multicultural expatriate environment. Cedwyn is closely involved with the supply chain industry in the region and has presented at industry conferences.

Gwendolyn Rodrigues' research interests are in the areas of macroeconomics and management. Gwen has worked on issues relating to globalization and intrapreneurship.

\section{REFERENCES}

1 Al-Hajri, G. The Impact of Sea-air Mode on Air Cargo Transport. Surrey, England: A-Z Group Ltd., 1999.

3. Arvis J.F., Mustra M.A., Panzer J., Ojala L. \& Naula T. 'Connecting to Compete: Trade Logistics in the Global Economy', The Logistics Performance index and its Indicators, International Bank for

Reconstruction and Development/World Bank, Washington, 2007.

4. Ashai Z., El Dahshan M., Kubba J., Talati H. \& Youssefi P. 'The Transport and Logistics Cluster in the United Arab Emirates', Harvard Business School, 2007. Available: http://www.isc.hbs.edu/pdf/Student_Projects/UAE_TransportLogisticsCluster_2007.pdf [Accessed 10 January 2008]

5. $\quad$ Baluch, I. 'Transport Logistics: Past, Present and Predictions', Winning Books, UAE, 2005.

6. Business Monitor International. Freight Transport Report Q1 - Singapore and Dubai, 2008. Available: http://www.businessmonitor.com [Accessed 13 February 2008]

7. Dubai Statistics Center. 'Dubai In Figures', Dubai Municipality, 2007. Available: http://www.dm.gov.ae/DMEGOV/OSI/dm-osiviewReportDetails?web_report_id=3879\&name_e=Dubai\%20In\%20Figures\%202007 [Accessed $10^{\text {th }}$ May 2008]

8. Dubai Strategic Plan. Highlights Dubai Strategic Plan 2015, 2007. Available: http://egov.dubai.ae/opt/CMSContent/Active/CORP/en/Documents/DSPE.pdf [Accessed 5 April 2008]. 
9. DWC. 'Dubai Sizes Europe’s Missed', 2007. Available:

http://www.dubaiworldcentralcomercialcity.com/Details.115.0.html?\&cHash=157f2f6c35\&tx ttnews\%5B backPid\%5D=114\&tx ttnews\%5Bpointer\%5D=1\&tx ttnews\%5Btt news\%5D=146 [Accessed 10th Feb 2008].

10. DWC. 'About Dubai World Central', 2008. Available: http://www.dwc.ae/home_about_dwc.html, [Accessed 10th April 2008].

11. Majdalani F., Koegler U. \& Kuge S. 'Middle East Transport and Logistics at the Crossroads', Booz Allen Hamilto, 2007. Available: http://www.boozallen.com/media/file/ME_Transport_Logistics_Crossroads.pdf, [Accessed 9 March 2007]

12. Han J.H., Chi Y.M., \& Cho H. 'Logistics Hub of Northeast Asia', Global Trade, Transportation and Logistics (GTTL), University of Washington, pp 2-4, 2004 Available: http://depts.washington.edu/gttl/StudentPapersAbstracts/2004/LogisticsHubNortheastAsia.pdf\#search=\%22 Logistics\%20Hub\%20of\%20Northeast\%20Asia\%20GTTL\%20\%22, [Accessed on $4^{\text {th }}$ July 2006]

13. International Monetary Fund. United Arab Emirates: Statistical Appendix, 2007. Available: http://www.imf.org/external/pubs/ft/scr/2007/cr07348.pdf, [Accessed 14 December 2007]

14. Lee, Y. and Hobday, M. 'Korea's New Globalisation Strategy: Can Korea Become a Business Hub in Northeast Asia?' Management Decision, 41(5):498-510, 2003.

15. Ministry of Trade and Industry Singapore. Report of the Working Group on Logistics: Developing Singapore into A Global Integrated Logistics Hub, 2005. Available: http://app.mti.gov.sg/default.asp?id=507, [Accessed Feb 2008]

16. Rodrik, D. 'Growth Strategies', in Handbook of Economic Growth, eds. P. Aghion \& S. Durlauf, Elsevier, North Holland, Chapter 14, 2005.

17. Shen, J. 'World City and Its Hinterland: The Transformation of Hong Kong as Trade and Logistics Hub', Shatin, Hong Kong, pp 3-4, 2004. Available: http://scholar.google.com/scholar?q=Shen\%20J\%202004\%20World\%20City\%20and\%20Its\%20Hinterland \%20The\%20Transformation\%20of\%20Hong\%20Kong\%20as\%20Trade\%20and\%20Logistics\%20Hub\&hl =en\&lr=\&oi=scholart, [Accessed August 2006]

18. Stiglitz, J. 'Some Lessons from the East Asian Miracle', World Bank Research Observer, Vol. 11, pp. 151$177,1996$.

19. Tahir, J. 'Free Economic Zones In Arab Countries In The Context Of Arab Free Trade Areas And WTO Arrangements: Trends And Future Prospects', in New Economic Developments and their Impact on Arab Economies, ed. A. Al-Kawaz, Elsevier, North Holland, 1999.

20. Tongzon, J. 'Strategies for Developing Logistics Hubs: The Case of Singapore', The 3rd Gwangyang Port Forum, 21-23 April 2004, Gwangyang City, S. Korea, 2004. Available: http://www.amc.edu.au/mlm/staff/jtongzon.html [Accessed July 2006]

21. UAE Interact. UAE Yearbook 2008, 2008. Available: http://www.uaeinteract.com/uaeint_misc/pdf_2008/index.asp\#year, [Accessed May 10 2008].

22. World Bank. The East Asian Miracle: Economic Growth and Public Policy, Oxford University Press, New York, 1993.

23. World Bank. Doing Business in 2008, IBRD/World Bank Washington D.C., 2008. Available: http://www.doingbusiness.org/documents/FullReport/2008/DB08_Full_Report.pdf [Accessed May 14 2008]. 